Article

\title{
Comparison of the Status of Interstitial Cells of Cajal in the Smooth Muscle of the Antrum and Pylorus in Diabetic Male and Female Patients with Severe Gastroparesis
}

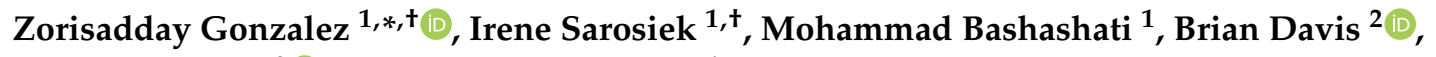 \\ Osvaldo Padilla $^{3}{ }^{(0)}$ and Richard McCallum ${ }^{1}$ \\ 1 Department of Gastroenterology, Center for Neurogastroenterology and GI Motility, Texas Tech University \\ Health Sciences Center, El Paso, TX 79905, USA; Irene.Sarosiek@ttuhsc.edu (I.S.); \\ Mohammad.Bashashati@ttuhsc.edu (M.B.); Richard.McCallum@ttuhsc.edu (R.M.) \\ 2 Department of General Surgery, Texas Tech University Health Sciences Center, El Paso, TX 79905, USA; \\ br.davis@ttuhsc.edu \\ 3 Department of Pathology, Texas Tech University Health Sciences Center, El Paso, TX 79905, USA; \\ osvaldo.padilla@ttuhsc.edu \\ * Correspondence: zgonzalez@phs.org; Tel.: +1-915-215-5191; Fax: +1-915-215-8641 \\ + These authors contribute equally to this work.
}

Received: 24 June 2020; Accepted: 4 August 2020; Published: 11 August 2020

\begin{abstract}
Females dominate in the area of gastroparesis (GP), making up to $70-80 \%$ of these patients. One attractive hypothesis is that females have less smooth muscle reserve and thus less resilience to recover from an insult. Our aim was to investigate if there are gender differences in the number of interstitial cells of Cajal (ICC) in the antral and pyloric smooth muscle of diabetic (DM) patients with severe gastroparesis refractory to standard medical management. Full thickness antral and pyloric biopsies were obtained during surgery to implant a gastric electrical stimulation system and perform a pyloroplasty. Thirty-eight DM patients ( $66 \%$ females, $n=25$; mean age 44$)$ who failed medical therapies provided antral biopsies. Pyloric tissue samples were also collected from 29 of these patients ( $65 \%$ females, $n=19$ ). Tissues were stained with H\&E and c-Kit for the presence of ICC. ICC depletion was defined as less than 10 cells/HPF. In the antrum, $40 \%$ of females had significant ICC depletion, similar to $38 \%$ in males. In the pylorus, $68 \%$ of females had depletion of ICC, compared to $80 \%$ depletion in males. When combining both antral and pyloric smooth muscle regions, ICC depletion was similar in males ( $40 \%$ ) when compared to females (38\%). In diabetic patients with severe GP, females and males showed similar degrees of reduction in antral ICC, while more males had depletion of pyloric smooth muscle ICC compared to their female counterparts. Future larger studies should focus on whether differences in other smooth muscle biomarkers can be identified between males and females.
\end{abstract}

Keywords: gastroparesis; interstitial cells of Cajal; female; gender; sex differences; estrogen; progesterone; nitric oxide synthase; nitrergic system; nitrergic dysfunction; serotonin

\section{Introduction}

Gastroparesis is a complex motility disorder characterized by delayed emptying of stomach contents after the exclusion of mechanical outlet obstruction is confirmed [1]. Symptoms are variable and may include nausea, vomiting, early satiety, abdominal discomfort, and/or postprandial fullness [2]. Worldwide, diabetes is more common in males compared to females with a 3:2 ratio [3]. However, 
approximately $75 \%$ of all diabetics with gastroparesis are females [4]. In fact, gastroparesis of all etiologies afflicts females significantly more than it does males, with a female to male ratio of $4: 1$, [5] with $70-80 \%$ of gastroparetic patients being female [3-7]. In a single-center study of patients with gastroparesis followed over six years, $82 \%$ of patients were female, and the mean age of onset of gastroparesis was 34 years [8]. The three most common causes of gastroparesis were idiopathic (36\%), diabetic (29\%), and post-surgical (13\%) [8]. In this same case series, diabetes mellitus accounted for almost one third of gastroparesis cases - the most widely recognized systemic disease known to be associated with gastroparesis [8,9].

A significant limitation to gaining a better understanding and awareness of the gender differences that exist in gastric emptying is the lack of comprehension that exists at the pathophysiological and cellular levels. For example, it is well established that gastric motility, including motor contractions and electrical pacemaking, are dependent on the function of the interstitial cells of Cajal (ICC), which have also been termed the "gut pacemaker cells" [10-15]. Loss of ICC, in addition to cellular damage and network degradation, are recognized cellular hallmarks in patients with gastroparesis. In a study by the National Institutes of Health (NIH) Gastroparesis Clinical Research Consortium (GpCRC), defects in ICC were noted to be the most common histopathological feature in both diabetic and idiopathic gastroparesis [16]. Furthermore, depletion of ICC is the only cellular abnormality shown to have a significant correlation with the severity of gastric emptying in patients with gastroparesis $[17,18]$. The minimum number of ICC required to support normal gastric emptying has been estimated to be approximately 3 ICC bodies per high-powered field in the gastric circular muscle [18]. Normal numbers of ICC are defined as $20 \pm 10$ cells per high powered field [19]. A depleted state of ICC is usually defined as less than 10 cells per high powered field based on averaging the ICC numbers in 20 high-powered fields per specimen [Figure 1]. Studies have shown that up to $40 \%$ of patients with gastroparesis have depleted numbers of ICC in the smooth muscle of both the gastric body and the antrum [20]. A reduced density of ICC has also been found in patients with gastroparesis-like symptoms, also known as chronic unexplained nausea and vomiting (CUNV) [21,22]. However, to our knowledge, no prior studies have been performed to examine whether abnormalities of ICC density exist between males and females, which might further explain the gender disparity present in gastroparesis. The goal of this research was to investigate gender-associated differences in the number of ICC in the antral and pyloric smooth muscle of diabetic patients with severe symptoms of gastroparesis who were refractory to all standard medical therapies and required surgical intervention.
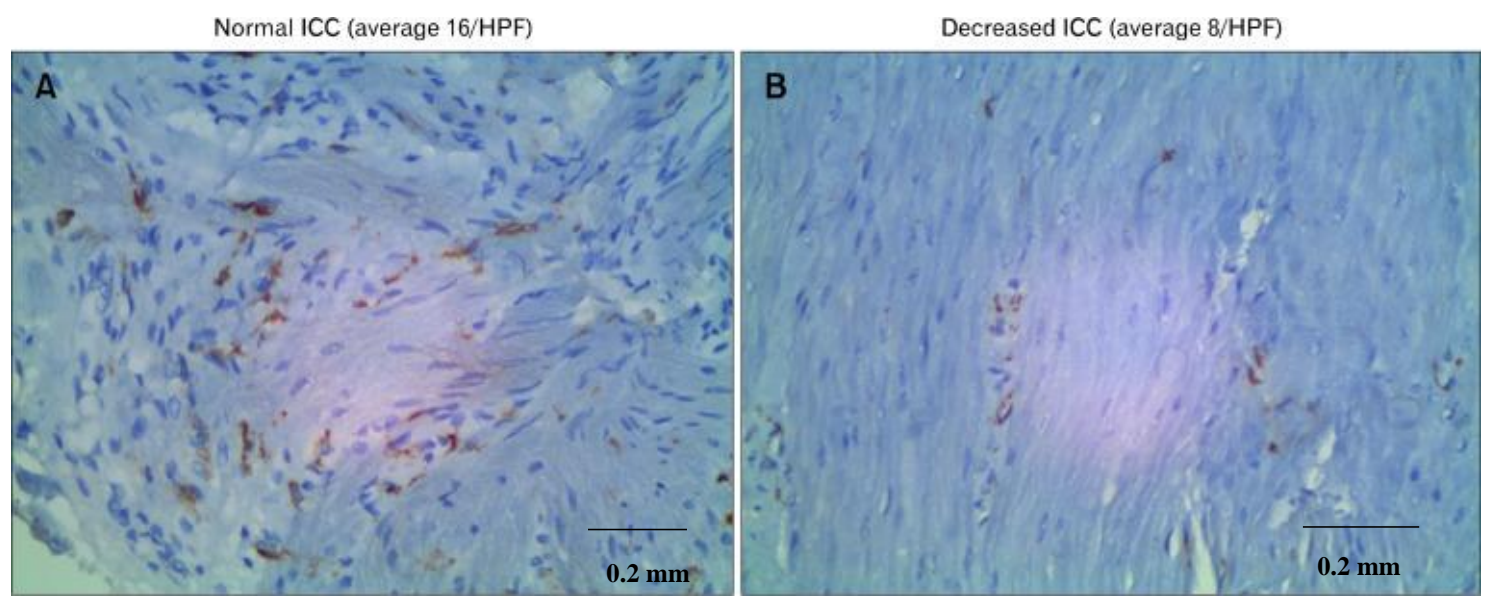

Figure 1. Antral muscularis propria immunostained with c-Kit primary antibody in a non-gastroparetic (A) and a gastroparetic patient (B). The images were taken at $40 \times$ magnification of formalin preserved full-thickness $1 \mathrm{~cm}^{2}$ surgically obtained gastric biopsies. Interstitial cells of Cajal (ICC) are spindle-shaped brown elements on the image. (A) Normal numbers of ICC which is $20 \pm 10$ (mean \pm 2SD) cells per high powered field (HPF). (B) Depleted numbers of ICC (less than 10 cells/HPF). The scale line represents $0.2 \mathrm{~mm}$. 


\section{Materials and Methods}

Thirty-eight patients ( $66 \%$ female, $n=25$, tissue was obtained and processed under an IRB-approved protocol where patient consent is required. TTUHSC IRB approval ID is E14018, and it was approved on 06/16/2014.) who were diagnosed with diabetic gastroparesis based on their medical history, clinical presentation and objective documentation of delayed gastric emptying (GET) provided by the standardized nuclear medicine $4 \mathrm{~h}$-scintigraphy test participated in this study [23]. During the time span of 2012-2020, these gastroparetic patients had been refractory to all available and even investigational therapies in order to meet criteria to receive gastric electrical stimulation (GES) therapy with the Enterra System (Medtronic Inc., Minneapolis, MN, USA) [24-27]. This surgery requires implantation of two intramuscular leads (Model 4351, Medtronic Inc.) with two electrodes located on the greater curvature of the stomach, which are connected with a pulse generating device (Model 7425G or 37800) placed subcutaneously in the abdominal wall [28-30]. In addition, a Heineke-Mikulicz pyloroplasty (PP), a well-established procedure, was simultaneously performed in the operating room [31-33]. During the implantation of GES with accompanying PP, full thickness antral and pyloric biopsies were obtained for further pathological and histological analyses [20].

\subsection{Histological Evaluation of the Biopsy Samples}

Paraffin-embedded formalin-fixed tissues were cut at 3-4- $\mu \mathrm{m}$-thick pieces and were placed on slides containing paired sections from each case. Then, the tissues were deparaffinized and immunostained with the antibody to CD117, by the Benchmark XT automated staining instrument. Briefly, the slides went through peroxidase block and antigen retrieval solutions before applying the primary antibodies (C-Kit clone YR145 from Cellmark, Rocklin, CA, USA). The slides were washed and then incubated with the secondary antibody followed by horseradish peroxidase (HPR). All elongated, spindle shape cells, were considered to be ICC $[10,34]$. Chromogen was then added and the slides were counter-stained by hematoxylin. Examination of approximately 20 high power fields and calculation of mean number of ICC cell bodies with nuclei were conducted [35]. By the definition previously established and described in the literature, depletion of ICC was defined when less than 10 cells/high power field (HPF) were identified in the antral and pyloric smooth muscle. This was assessed by examining $20 \mathrm{HPF}$ and then averaging the ICC population from all of these fields. In addition, we have a database of non-gastroparetic patients who are undergoing surgery for placement of a feeding jejunostomy tube, where antral biopsies were obtained as "controls". Other patients who were undergoing a Whipple procedure for pancreatic cancer, or who were scheduled for a subtotal gastrectomy and gastro-jejunostomy (Roux-en-Y procedure) due to peptic ulcer disease provided a sample of pyloric sphincter tissue as "control" patients for identifying a "normal" number of ICC in the pylorus. A "normal" ICC population was determined as $>10$ cells/HPF in both the antrum and pylorus [10]. We limited the study group to only diabetic gastroparetics based on the dominance of the etiology of gastroparesis at our Academic Gastroenterology Motility Center. There is a high prevalence of type 2 diabetes in the setting of metabolic syndrome among a predominantly Hispanic population in Southwest Texas.

\subsection{Statistical Analysis}

Categorical data were presented as frequencies (\%), and were analyzed by using the chi-square test. Numerical/quantitative data were presented as the mean and standard deviation (range) and compared with an independent t-test. $p<0.05$ was considered statistically significant. All analyses were performed using SAS statistical software (Version 9.1 of the SAS System for Windows, SAS Institute Inc. Cary, NC, USA). 


\section{Results}

Out of 42 diabetic gastroparetic (DMGP) patients who had failed all available medical therapies and had received a GES with accompanying PP, 38 subjects ( $66 \%$ female, $n=25)$ provided adequately sized antral biopsies and 29 subjects $(65 \%$ female, $n=19)$ provided adequately sized pyloric biopsy samples. The mean age of all participants was 44 (range 25-71). The mean duration of DM was 16.3 years (range $3-50$ ). The mean duration of gastroparesis symptoms was 5.1 years (range 1-15). The mean number of ICC in the antrum for all DMGP patients was $11.5( \pm 5.3)$. This was significantly higher than the mean number of ICC in the pyloric smooth muscle which was $7.4( \pm 4.7)(p<0.01)$. Depletion of antral ICC, defined as $<10$ cells per HPF, was detected in 15 patients (39\%), compared to depletion of pyloric ICC observed in 21 gastroparetics $(72 \%)(p<0.01)$. A reduction in ICCs in both locations was recorded in 10 of 29 patients (34\%).

All participating gastroparetics were divided into two groups based on their gender. The mean number of antral ICC for 25 females was $11.1( \pm 4.3)$ similar to $12.5( \pm 7.0)$ in 13 males (total 38 subjects who provided antral tissue samples). The mean number of pyloric ICC for 19 females was 7.9 $( \pm 4.4)$ similar to $6.4( \pm 5.4)$ ICCs in 10 males (total 29 subjects who provided pyloric tissue samples). In the antrum, $40 \%$ of females had similar depletion of ICC density (by definition, $<10$ cells/HPF) compared to $38 \%$ in males in Figure 2 and Table 1 . In the pylorus, more males ( $80 \%)$ had reduced numbers of ICC (by definition, $<10$ cells/HPF) compared to $68 \%$ of females in Figure 3 and Table 1 . By examining for the presence of depleted ICC $(<10 / \mathrm{HPF})$ in both the antral and pyloric smooth muscle tissues, we determined that $32 \%$ of female and $40 \%$ of male diabetic gastroparetic patients met this criteria (Table 1).

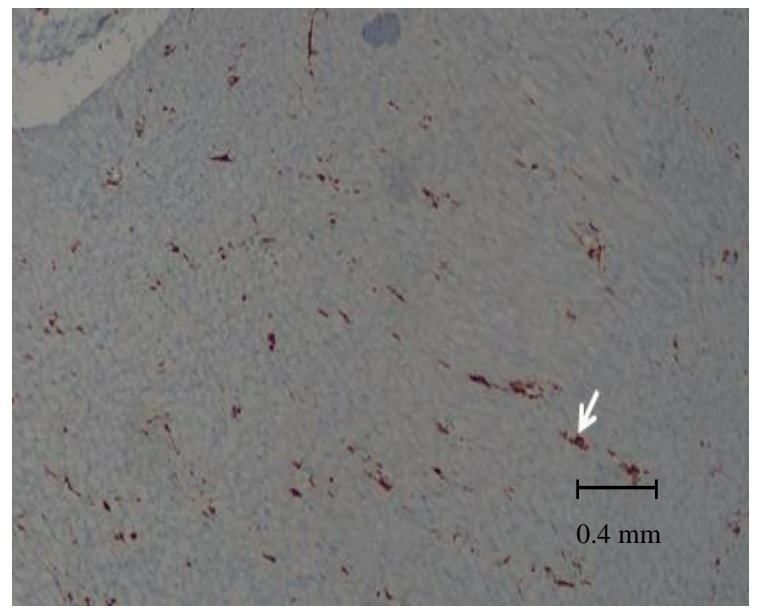

(A)

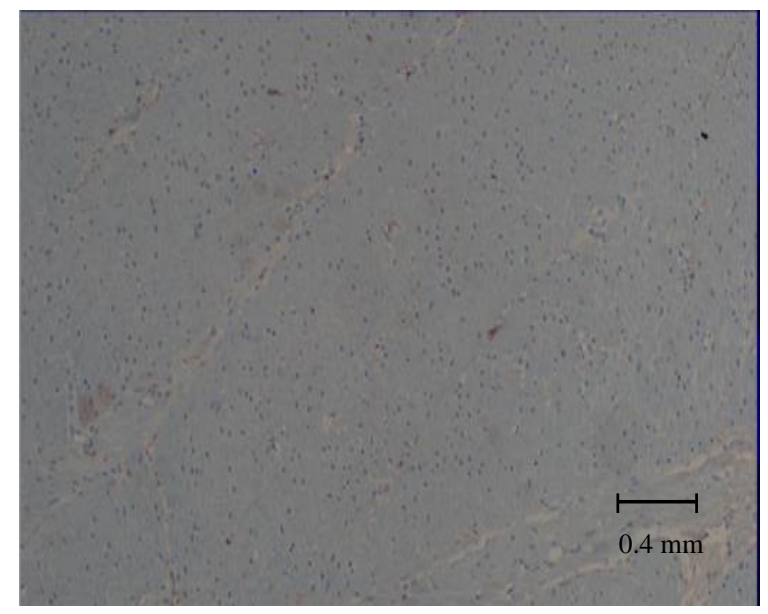

(B)

Figure 2. Antral interstitial cells of Cajal (ICC) in a control (A) compared to a gastroparetic patient (B) (20x). White arrows indicate c-Kit positive cells. Thirty-eight diabetics (66\% F, $n=25)$ provided adequately sized antral biopsies. In the antrum, $40 \%$ of females had depletion of ICC (by definition, $<10$ cells/HPF), compared to $38 \%$ in males. The scale line represents $0.4 \mathrm{~mm}$. 
Table 1. Results of ICC status based on gender and gastric region in diabetic gastroparetic patients who received gastric electrical stimulation systems and pyloroplasty for their severe gastroparesis (GP) symptoms.

\begin{tabular}{|c|c|c|c|c|}
\hline \multicolumn{5}{|c|}{ Mean Number of ICC/HPF in the Antrum vs. Pylorus } \\
\hline \multicolumn{2}{|c|}{ Antrum: Mean $11.5( \pm 5.3)$ Range (3-10) } & \multicolumn{2}{|c|}{ Pylorus: Mean $7.4( \pm 4.7)$ Range (1-9) } & \multirow{2}{*}{$\begin{array}{l}p<0.01 \\
p \text { Value }\end{array}$} \\
\hline & ICC & Female & Male & \\
\hline \multirow{2}{*}{$\begin{array}{c}\text { Antrum } \\
\mathrm{F} n=25(66 \%) \\
\mathrm{M} n=13(34 \%)\end{array}$} & Mean \# of ICC for & $11.1( \pm 4.3)$ & $12.5( \pm 7.0)$ & n.s. \\
\hline & $\begin{array}{c}\text { ICC less }<10 \\
\text { cells } / \mathrm{HPF}\end{array}$ & $10(40 \%)$ & $5(38 \%)$ & n.s. \\
\hline \multirow{2}{*}{$\begin{array}{c}\text { PYLORUS } \\
\text { F } n=19(65 \%) \\
\text { M } n=10(35 \%)\end{array}$} & Mean \# of ICC for & $7.9( \pm 4.4)$ & $6.4( \pm 5.4)$ & n.s. \\
\hline & $\begin{array}{c}\text { ICC less }<10 \\
\text { cells } / \mathrm{HPF}\end{array}$ & $13(68 \%)$ & $8(80 \%)$ & n.s. \\
\hline \multicolumn{2}{|c|}{ ICC less $<10$ cells/HPF in both regions } & $6(32 \%)$ & $4(40 \%)$ & n.s. \\
\hline
\end{tabular}

n.s. = non-significant.
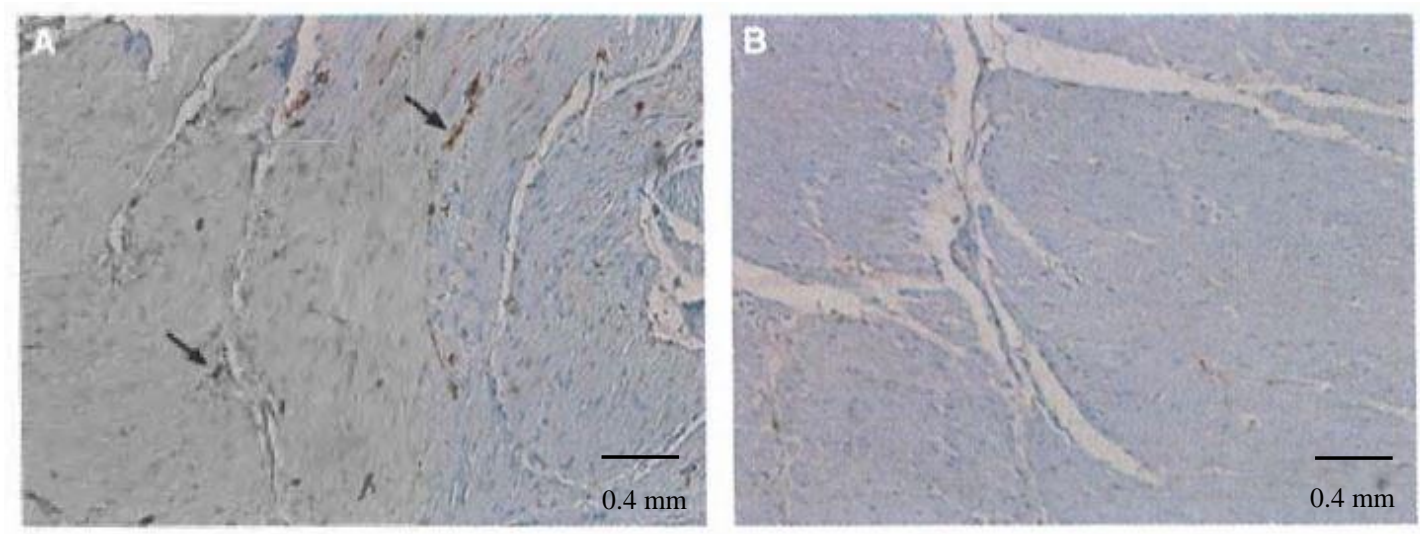

Figure 3. Pyloric interstitial cells of Cajal (ICC) in a control (A) compared to a gastroparetic patient (B) (20x). Pyloric ICC are depleted in this gastroparetic patient. Black arrows indicate c-Kit positive cells. Twenty-six diabetics $(42 \% \mathrm{~F}, n=16)$ provided adequately sized pyloric biopsies. In the pylorus, $68 \%$ of females had depletion of ICC $(<10$ cells/HPF), compared to $80 \%$ in males. The scale line represents $0.4 \mathrm{~mm}$.

\section{Discussion}

Our study showed that females and males with severe symptoms of refractory diabetic gastroparesis requiring a surgical gastric electrical stimulator (GES) and pyloroplasty (PP) intervention have comparable patterns of ICC population in antral smooth muscle samples, and specifically, a similar frequency for ICC depletion with $40 \%$ in females and $38 \%$ in males. In the pyloric smooth muscle, depletion of ICC density was more frequent in males ( $80 \%$ in males vs. $68 \%$ in females). These observations have to be interpreted with the knowledge that the antrum is where most of the stomach contractility and trituration of food occurs, [19] and females have been found to have more impaired antral contractility compared to males [36]. For example, in a study using antroduodenal manometry, the frequency of antral contractions decreased after a meal, compared to a temporary increase in contractility in men [37]. To our knowledge, this is the first investigation comparing ICC status in the smooth muscle of the antrum and pylorus between males and females diagnosed with severe, medically refractory diabetic gastroparesis. We believe that one of the major reasons for the limitation of ICC data in the literature is explained by the fact that gastric smooth muscle tissue samples are currently only able to be obtained during surgery. Approximately $30 \%$ of gastroparesis (GP) patients fail all standard medical therapies and require this surgery. Hence, the gastroparetic 
patients, whose smooth muscles have been studied and reported here, represent a severe subset of the gastroparetic population.

The interstitial cells of Cajal (ICC) are the pacemaker cells of the stomach [19]. They are mesenchymal cells embedded within the musculature of the gastrointestinal tract, and they play a critical role in the regulation of gut and intestinal contractile motility by generating spontaneous slow electrical waves [38]. Damage or loss of ICC is known to be associated with significant disturbances in gastrointestinal motility [39]. In fact, it is the depletion of pacemaker ICC that marks the cellular basis of gastroparesis, and is a key histopathological defect in this disease. For example, a decrease from 60 up to $100 \%$ in ICC density was noted in the smooth muscle of the gastric antrum and body by histologic studies in patients with type 1 diabetes, and this reduced ICC population was associated with gastroparesis and gastro-electric dysrhythmias [40]. To our knowledge, there are no studies available that distinguishes the status of ICC between men and women in gastroparesis. For example, in the largest National Institute of Diabetes and Digestive and Kidney Diseases (NIDDK) GpCRC study describing histologic abnormalities from full-thickness gastric biopsies comparing $20[65 \% \mathrm{~F}]$ idiopathic gastroparetic (IDGP) versus 20 [75\% F] diabetic gastroparetic patients (DMGP), loss of ICC defined by a $>25 \%$ decrease in c-Kit expression was found to be the most common defect in both populations [16]. However, cellular differences between men and women were not assessed in this landmark study.

Diabetic gastroparesis is a disease that mainly affects women [7], just as females significantly dominate all other etiological subtypes of gastroparesis with a $70-80 \%$ presence in the published data and clinical trials $[5,41]$. The biological mechanisms that explain this gender bias are not completely understood. One proposed hypothesis is that sex steroid hormones may play an important role in the development and progression of gastric motility dysfunction (i.e., estrogen and progesterone) [42-44]. In normal healthy women, gastric emptying for both liquids and solids has been observed to be slower compared to healthy men in some, $[37,42,45]$ but not all studies $[46,47]$. In diabetic women, gastric emptying has also been shown to be slower compared to diabetic males [48]. Gender differences in gastric emptying have frequently been attributed to the effects of sex hormones, namely estrogen and progesterone with many of their receptors found throughout the gastrointestinal tract: [36,49] while progesterone accelerates gastric emptying, estrogen slows it down [50]. Some studies have demonstrated that exogenous administration of estrogen further inhibits gastric emptying [51-53]. Other proposed physiologic differences which might contribute to the female preponderance of gastroparesis include observations that females have more prolonged fundic relaxation, decreased antral contractility, altered neuroenteric transmission, and visceral hypersensitivity compared to males $[7,36,43,54,55]$. Furthermore, women with idiopathic gastroparesis have been found to be disproportionately more symptomatic compared to men, specifically with more severe nausea and early satiety, and this has been attributed to slower emptying of the stomach in females $[7,56]$.

Loss of nitric oxide (NO) resulting in an impaired nitrergic system is yet another proposed mechanism which might possibly contribute to the disparity observed in gastric emptying between men and women $[41,56]$. NO is a significant inhibitory nonadrenergic, noncholinergic neurotransmitter that plays a critical role in gastric motility [57]. NO is synthesized by neuronal nitric oxide synthase (nNOS), an enzyme found in the enteric nitrergic nerves in the myenteric plexus [58]. The dimerization of nNOS is critical for its catalytic activity, and therefore changes in nNOS expression and function can lead to impaired gastric emptying in diabetic patients $[44,56]$. Some studies have shown the nitrergic system may be regulated by endogenous hormones [56,59,60]. A study from our group in diabetic rats demonstrated that estrogen can slow gastric emptying, partly due to the downregulation of nitric oxide-mediated smooth muscle relaxation in the gut [60]. Additionally, long-standing estrogen deficiency in this murine model resulted in development of gastroparesis by altering neuronal nitric oxide synthase (nNOS) function [44]. Thus, decreased nitric oxide levels resulting in nitrergic system dysfunction is one hypothesis about the gender disparity observed in gastroparesis between males and females. 
One limitation to our study could be the relatively small patient sample size. However, to our knowledge, these antral and pyloric tissue samples obtained from surgical biopsies represent the largest single-center collection of surgically obtained smooth muscle in the world. Further studies with a larger population in the future will be important in confirming and expanding our findings. Another possible limitation is that the selection of our patients was restricted to those with refractory diabetic gastroparesis. Our focus was on diabetic GP, which dominates the etiology of GP at our medical center. It would also be interesting to see if similar results might be found in patients with mild or moderate symptoms of gastroparesis. In the future, antral biopsies will be collected not only via surgical access, but will be available from standard upper gastrointestinal procedures. The utilization of an endoscopic submucosal dissection tunneling approach will serve as a safe technique to obtain gastric smooth muscle tissue samples, and thus will greatly enlarge the database currently available, not relying on refractory gastroparesis cases. In addition, since all etiologies of gastroparesis are dominated by females, and since "idiopathic" is the largest subgroup of gastroparetic patients, certainly their ICC status should be investigated in the future.

In conclusion, in diabetic patients with severe GP, our data showed that females and males have similar degrees of reduction in antral ICC, while in pyloric smooth muscle, ICC depletion was more frequent in males. This study is important because, to date, there has not been a real attempt to investigate a biological marker to assess the gender disparity that exists in gastroparesis. One question that arises is whether ICC could be a marker for the chronic injury of gastroparesis. If so, this would infer that the gastric smooth muscle of females may have less ability to regenerate their muscle function and structure after sex hormone/receptor-mediated imbalances and mechanistic alterations created by chronic exposure to biochemical and biological injuries. This hypothesis implies that females have a lower threshold for insult and there is a genetically predisposed impaired resilience among females to recover from a pathophysiological insult, which in turn might produce a diminished ability to restore molecular and histological damage. The explanations for this greater vulnerability to gastroparesis in females remains to be resolved.

Author Contributions: Data curation, I.S.; Statistical analysis, M.B. Formal analysis, R.M.; Investigation, B.D. and O.P.; Methodology, I.S., B.D. and O.P.; Project administration, R.M.; Supervision, R.M.; Writing-original draft, Z.G.; Writing-review \& editing, I.S. and R.M. All authors have read and agreed to the published version of the manuscript.

Funding: This research received no external funding.

Conflicts of Interest: The authors declare that they have no known competing financial interests or personal relationships that could have appeared to influence the work reported in this paper.

\section{References}

1. Parkman, H.P.; Hasler, W.L.; Fisher, R.S. American Gastroenterological Association technical review on the diagnosis and treatment of gastroparesis. Gastroenterology 2004, 127, 1592-1622. [CrossRef] [PubMed]

2. Revicki, D.A.; Rentz, A.M.; Dubois, D.; Kahrilas, P.; Stanghellini, V.; Talley, N.J.; Tack, J. Development and validation of a patient-assessed gastroparesis symptom severity measure: The Gastroparesis Cardinal Symptom Index. Aliment. Pharm. 2003, 18, 141-150. [CrossRef] [PubMed]

3. Gale, E.A.; Gillespie, K.M. Diabetes and Gender. Diabetologia 2001, 44. [CrossRef] [PubMed]

4. Parkman, H.P.; Yates, K.; Hasler, W.L.; Nguyen, L.; Pasricha, P.J.; Snape, W.J.; Farrugia, G.; Koch, K.L.; Calles, J.; Abell, T.L.; et al. Similarities and differences between diabetic and idiopathic gastroparesis. Clin. Gastroenterol. Hepatol. 2011, 9, 1056-1064; quiz e1133-1054. [CrossRef]

5. Jung, H.K.; Choung, R.S.; Locke, G.R., 3rd; Schleck, C.D.; Zinsmeister, A.R.; Szarka, L.A.; Mullan, B.; Talley, N.J. The incidence, prevalence, and outcomes of patients with gastroparesis in Olmsted County, Minnesota, from 1996 to 2006. Gastroenterology 2009, 136, 1225-1233. [CrossRef]

6. Dudekula, A.; O'Connell, M.; Bielefeldt, K. Hospitalizations and testing in gastroparesis. J. Gastroenterol. Hepatol. 2011, 26, 1275-1282. [CrossRef] 
7. $\quad$ Parkman, H.P.; Yates, K.; Hasler, W.L.; Nguyen, L.; Pasricha, P.J.; Snape, W.J.; Farrugia, G.; Koch, K.L.; Abell, T.L.; McCallum, R.W.; et al. Clinical features of idiopathic gastroparesis vary with sex, body mass, symptom onset, delay in gastric emptying, and gastroparesis severity. Gastroenterology 2011, 140, 101-115. [CrossRef]

8. Soykan, I.; Sivri, B.; Sarosiek, I.; Kiernan, B.; McCallum, R.W. Demography, clinical characteristics, psychological and abuse profiles, treatment, and long-term follow-up of patients with gastroparesis. Dig. Dis. Sci. 1998, 43, 2398-2404. [CrossRef]

9. Camilleri, M.; Parkman, H.P.; Shafi, M.A.; Abell, T.L.; Gerson, L. Clinical guideline: Management of gastroparesis. Am. J. Gastroenterol. 2013, 108, 18-37; quiz 38. [CrossRef]

10. Lin, Z.; Sarosiek, I.; Froster, J.; Damjanov, I.; Hou, Q.; McCallum, R.W. Association of the Status of Interstitial Cells of Cajal and Electrogastrogram Parameters, Gastric Emptying and Symptoms in Patients with Gastroparesis. Neurogastroenterol. Motil. 2010, 22, 56-61.

11. Ördög, T.; Ward, S.M.; Sanders, K.M. Interstitial Cells of Cajal Generate Electrical Slow Waves in the Murine Stomach. J. Physiol. 1999, 518. [CrossRef]

12. Huizinga, J.D.; Thuneberg, L.; Kluppel, M.; Malysz, J.; Mikkelsen, H.B.; Bernstein, A. W/kit gene required for interstitial cells of Cajal and for intestinal pacemaker activity. Nature 1995, 373, 347-349. [CrossRef] [PubMed]

13. Ward, S.M.; Burns, A.J.; Torihashi, S.; Sanders, K.M. Mutation of the proto-oncogene c-kit blocks development of interstitial cells and electrical rhythmicity in murine intestine. J. Physiol. 1994, 480, 91-97. [CrossRef] [PubMed]

14. Huizinga, J.D.; Zarate, N.; Farrugia, G. Physiology, Injury, and Recovery of Interstitial Cells of Cajal: Basic and Clinical Science. Gastroenterology 2009, 137. [CrossRef] [PubMed]

15. Sanders, K.M. A Case for Interstitial Cells of Cajal as Pacemakers and Mediators of Neurotransmission in the Gastrointestinal Tract. Gastroenterology 1996, 111. [CrossRef] [PubMed]

16. Grover, M.; Farrugia, G.; Lurken, M.S.; Bernard, C.E.; Faussone-Pellegrini, M.S.; Smyrk, T.C.; Parkman, H.P.; Abell, T.L.; Snape, W.J.; Hasler, W.L.; et al. Cellular changes in diabetic and idiopathic gastroparesis. Gastroenterology 2011, 140, 1575-1585. [CrossRef]

17. Grover, M.; Bernard, C.E.; Pasricha, P.J.; Lurken, M.S.; Faussone-Pellegrini, M.S.; Smyrk, T.C.; Parkman, H.P.; Abell, T.L.; Snape, W.J.; Hasler, W.L.; et al. Clinical-histological associations in gastroparesis: Results from the Gastroparesis Clinical Research Consortium. NeuroGastroenterol. Motil. 2012, 24, 531-539. [CrossRef]

18. Wells, C.; O'Grady, G. Interstitial Cells of Cajal. Nature 2019, 267-274. [CrossRef]

19. Bashashati, M.; McCallum, R.W. Is Interstitial Cells of Cajal-opathy Present in Gastroparesis? J. NeuroGastroenterol. Motil. 2015, 21, 486-493. [CrossRef]

20. Moraveji, S.; Bashashati, M.; Elhanafi, S.; Sunny, J.; Sarosiek, I.; Davis, B.; Torabi, A.; McCallum, R.W. Depleted interstitial cells of Cajal and fibrosis in the pylorus: Novel features of gastroparesis. NeuroGastroenterol. Motil. 2016, 28, 1048-1054. [CrossRef]

21. Bashashati, M.; McCallum, R.W. Motility: Is 'ICC-opathy' Present in Gastroparesis-Like Syndrome? Nat. Rev. Gastroenterol. Hepatol. 2015, 12. [CrossRef]

22. Angeli, T.R.; Cheng, L.K.; Du, P.; Wang, T.H.; Bernard, C.E.; Vannucchi, M.G.; Faussone-Pellegrini, M.S.; Lahr, C.; Vather, R.; Windsor, J.A.; et al. Loss of Interstitial Cells of Cajal and Patterns of Gastric Dysrhythmia in Patients With Chronic Unexplained Nausea and Vomiting. Gastroenterology 2015, 149. [CrossRef] [PubMed]

23. Abell, T.L.; Camilleri, M.; Donohoe, K.; Hasler, W.L.; Lin, H.C.; Maurer, A.H.; McCallum, R.W.; Nowak, T.; Nusynowitz, M.L.; Parkman, H.P.; et al. Consensus recommendations for gastric emptying scintigraphy: A joint report of the American Neurogastroenterology and Motility Society and the Society of Nuclear Medicine. J. Nucl. Med. Technol. 2008, 36, 44-54. [CrossRef] [PubMed]

24. Cutts, T.F.; Luo, J.; Starkebaum, W.; Rashed, H.; Abell, T.L. Is gastric electrical stimulation superior to standard pharmacologic therapy in improving GI symptoms, healthcare resources, and long-term health care benefits? NeuroGastroenterol. Motil. 2005, 17, 35-43. [CrossRef] [PubMed]

25. Anand, C.; Al-Juburi, A.; Familoni, B.; Rashed, H.; Cutts, T.; Abidi, N.; Johnson, W.D.; Minocha, A.; Abell, T.L. Gastric electrical stimulation is safe and effective: A long-term study in patients with drug-refractory gastroparesis in three regional centers. Digestion 2007, 75, 83-89. [CrossRef]

26. Jayanthi, N.V.; Dexter, S.P.; Sarela, A.I. Gastric electrical stimulation for treatment of clinically severe gastroparesis. J. Minim. Access. Surg. 2013, 9, 163-167. [CrossRef]

27. Maranki, J.L.; Lytes, V.; Meilahn, J.E.; Harbison, S.; Friedenberg, F.K.; Fisher, R.S.; Parkman, H.P. Predictive factors for clinical improvement with Enterra gastric electric stimulation treatment for refractory gastroparesis. Dig. Dis. Sci. 2008, 53, 2072-2078. [CrossRef] 
28. Forster, J.; Sarosiek, I.; Lin, Z.; Durham, S.; Denton, S.; Roeser, K.; McCallum, R.W. Further Experience With Gastric Stimulation to Treat Drug Refractory Gastroparesis. Am. J. Surg. 2003, 186. [CrossRef]

29. Lahr, C.J.; Griffith, J.; Subramony, C.; Halley, L.; Adams, K.; Paine, E.R.; Schmieg, R.; Islam, S.; Salameh, J.; Spree, D.; et al. Gastric Electrical Stimulation for Abdominal Pain in Patients With Symptoms of Gastroparesis. Am. Surg. 2013, 79, 457-464.

30. Keller, D.S.; Parkman, H.P.; Boucek, D.O.; Sankineni, A.; Meilahn, J.E.; Gaughan, J.P.; Harbison, S. Surgical Outcomes After Gastric Electric Stimulator Placement for Refractory Gastroparesis. J. Gastrointest. Surg. Off. J. Soc. Surg. Aliment. Tract 2013, 17. [CrossRef]

31. Davis, B.R.; Sarosiek, I.; Bashashati, M.; Alvarado, B.; McCallum, R.W. The Long-Term Efficacy and Safety of Pyloroplasty Combined with Gastric Electrical Stimulation Therapy in Gastroparesis. J. Gastrointest. Surg. 2017, 21, 222-227. [CrossRef]

32. Bashashati, M.; Sarosiek, I.; Davis, B.R.; Diaz,J.R.; Padilla, O.; Espino, K.; McCallum, R.W. Mo1599_Combined Gastric Electrical Stimulation Pyloroplasty Improves Gastroparesis Symptoms and Gastric Emptying Without Affecting the Count of Antral Interstitial Cells of Cajal. Gastroenterology 2019, 156. [CrossRef]

33. Toro, J.P.; Lytle, N.W.; Patel, A.D.; Davis, S.S., Jr.; Christie, J.A.; Waring, J.P.; Sweeney, J.F.; Lin, E. Efficacy of laparoscopic pyloroplasty for the treatment of gastroparesis. J. Am. Coll. Surg. 2014, 218, 652-660. [CrossRef] [PubMed]

34. Harberson, J.; Thomas, R.M.; Harbison, S.P.; Parkman, H.P. Gastric Neuromuscular Pathology in Gastroparesis: Analysis of Full-Thickness Antral Biopsies. Dig. Dis. Sci. 2010, 55, 359-370.

35. Bashashati. Pathological Findings of the Antral and Pyloric Smooth Muscle in Patients with Gastroparesis-Like Syndrome Compared to Gastroparesis: Similarities and Differences. Available online: https://elpaso.ttuhsc. edu/ (accessed on 8 August 2020).

36. Zia, J.K.; Heitkemper, M.M. Upper Gastrointestinal Tract Motility Disorders in Women, Gastroparesis, and Gastroesophageal Reflux Disease. Gastroenterol. Clin. N. Am. 2016, 45, 239-251. [CrossRef] [PubMed]

37. Knight, L.C.; Parkman, H.P.; Brown, K.L.; Miller, M.A.; Trate, D.M.; Maurer, A.H.; Fisher, R.S. Delayed gastric emptying and decreased antral contractility in normal premenopausal women compared with men. Am. J. Gastroenterol. 1997, 92, 968-975. [PubMed]

38. Hennig, G.W.; Spencer, N.J.; Jokela-willis, S.; Bayguinov, P.O.; Lee, H.T.; Ritchie, L.A.; Ward, S.M.; Smith, T.K.; Sanders, K.M. ICC-MY Coordinate Smooth Muscle Electrical and Mechanical Activity in the Murine Small Intestine. NeuroGastroenterol. Motil. Off. J. Eur. Gastrointest. Motil. Soc. 2010, 22. [CrossRef]

39. Sanders, K.M. Interstitial Cells of Cajal at the Clinical and Scientific Interface. J. Physiol. 2006, 576. [CrossRef]

40. Long, Q.L.; Fang, D.C.; Shi, H.T.; Luo, Y.H. Gastro-electric dysrhythm and lack of gastric interstitial cells of cajal. World J. Gastroenterol. 2004, 10, 1227-1230. [CrossRef]

41. Gangula, P.R.; Maner, W.L.; Micci, M.A.; Garfield, R.E.; Pasricha, P.J. Diabetes induces sex-dependent changes in neuronal nitric oxide synthase dimerization and function in the rat gastric antrum. Am. J. Physiol. Gastrointest. Liver Physiol. 2007, 292, G725-G733. [CrossRef]

42. Datz, F.L.; Christian, P.E.; Moore, J. Gender-related differences in gastric emptying. J. Nucl. Med. 1987, 28, 1204-1207.

43. Hutson, W.R.; Roehrkasse, R.L.; Wald, A. Influence of gender and menopause on gastric emptying and motility. Gastroenterology 1989, 96, 11-17. [CrossRef]

44. Ravella, K.; Al-Hendy, A.; Sharan, C.; Hale, A.B.; Channon, K.M.; Srinivasan, S.; Gangula, P.R. Chronic estrogen deficiency causes gastroparesis by altering neuronal nitric oxide synthase function. Dig. Dis. Sci. 2013, 58, 1507-1515. [CrossRef] [PubMed]

45. Camilleri, M.; Iturrino, J.; Bharucha, A.E.; Burton, D.; Shin, A.; JEONG, I.D.; Zinsmeister, A.R. Performance characteristics of scintigraphic measurement of gastric emptying of solids in healthy participants. NeuroGastroenterol. Motil. 2012, 24, 1076-e1562. [CrossRef] [PubMed]

46. Petring, O.U.; Flachs, H. Inter- and intrasubject variability of gastric emptying in healthy volunteers measured by scintigraphy and paracetamol absorption. Br. J. Clin. Pharm. 1990, 29, 703-708. [CrossRef] [PubMed]

47. Madsen, J.L. Effects of gender, age, and body mass index on gastrointestinal transit times. Dig. Dis. Sci. 1992, 37, 1548-1553. [CrossRef]

48. Jones, K.L.; Russo, A.; Stevens, J.E.; Wishart, J.M.; Berry, M.K.; Horowitz, M. Predictors of delayed gastric emptying in diabetes. Diabetes Care 2001, 24, 1264-1269. [CrossRef] 
49. Yang, X.; Guo, Y.; He, J.; Zhang, F.; Sun, X.; Yang, S.; Dong, H. Estrogen and estrogen receptors in the modulation of gastrointestinal epithelial secretion. Oncotarget 2017, 8, 97683-97692. [CrossRef]

50. Chen, T.S.; Doong, M.L.; Chang, F.Y.; Lee, S.D.; Wang, P.S. Effects of sex steroid hormones on gastric emptying and gastrointestinal transit in rats. Am. J. Physiol. 1995, 268, G171-G176. [CrossRef]

51. Hogan, A.M.; Collins, D.; Baird, A.W.; Winter, D.C. Estrogen and its role in gastrointestinal health and disease. Int. J. Colorectal Dis. 2009, 24, 1367-1375. [CrossRef]

52. Liu, C.Y.; Chen, L.B.; Liu, P.Y.; Xie, D.P.; Wang, P.S. Effects of progesterone on gastric emptying and intestinal transit in male rats. World J. Gastroenterol. 2002, 8, 338-341. [CrossRef]

53. Iino, S.; Horiguchi, S.; Horiguchi, K. Interstitial cells of Cajal in the gastrointestinal musculature of W(jic) c-kit mutant mice. J. Smooth Muscle Res. Nihon Heikatsukin Gakkai Kikanshi 2011, 47, 111-121. [CrossRef]

54. Mones, J.; Carrio, I.; Calabuig, R.; Estorch, M.; Sainz, S.; Berna, L.; Vilardell, F. Influence of the menstrual cycle and of menopause on the gastric emptying rate of solids in female volunteers. Eur. J. Nucl. Med. 1993, 20, 600-602. [CrossRef] [PubMed]

55. Avalos, D.N.P.; McCallum, R.W. Understanding the Etiology and Spectrum of Idiopathic Gastroparesis. Pract. Gastroenterol. 2017, 42, 38-50.

56. Gangula, P.R.; Sekhar, K.R.; Mukhopadhyay, S. Gender bias in gastroparesis: Is nitric oxide the answer? Dig. Dis. Sci. 2011, 56, 2520-2527. [CrossRef] [PubMed]

57. Takahashi, T. Pathophysiological Significance of Neuronal Nitric Oxide Synthase in the Gastrointestinal Tract. J. Gastroenterol. 2003, 38. [CrossRef]

58. Förstermann, U.; Sessa, W.C. Nitric Oxide Synthases: Regulation and Function. Eur. Heart J. 2012, 33. [CrossRef]

59. Lekontseva, O.; Chakrabarti, S.; Jiang, Y.; Cheung, C.C.; Davidge, S.T. Role of Neuronal Nitric-Oxide Synthase in Estrogen-Induced Relaxation in Rat Resistance Arteries. J. Pharmacol. Exp. Ther. 2011, 339. [CrossRef]

60. Showkat Ali, M.; Tiscareno-Grejada, I.; Locovei, S.; Smiley, R.; Collins, T.; Sarosiek, J.; McCallum, R. Gender and estradiol as major factors in the expression and dimerization of nNOSalpha in rats with experimental diabetic gastroparesis. Dig. Dis. Sci. 2012, 57, 2814-2825. [CrossRef]

(C) 2020 by the authors. Licensee MDPI, Basel, Switzerland. This article is an open access article distributed under the terms and conditions of the Creative Commons Attribution (CC BY) license (http://creativecommons.org/licenses/by/4.0/). 